\title{
Nutritional potentialities of some tree leaves based on polyphenols and rumen in vitro gas production
}

\author{
K. S. Giridhar ${ }^{1}$, T. M. Prabhu², K. Chandrapal Singh², V. Nagabhushan ${ }^{3}$, T. Thirumalesh ${ }^{4}$, Y. B. Rajeshwari ${ }^{5}$ and
} B. C. Umashankar²

1. Department of Animal Nutrition, Veterinary College, Gadag, Karnataka, India; 2. Department of Animal Nutrition, Veterinary College, Bengaluru, Karnataka, India; 3. Department of Animal Nutrition, Veterinary College, Shivamogga, Karnataka, India; 4. Department of LFC, Veterinary College, Shivamogga, Karnataka, India; 5. Department of LPM, Veterinary College, Bengaluru, Karnataka, India.

Corresponding author: K. S. Giridhar, e-mail: giridharksdr@gmail.com

Co-authors: TMP: prabhutmann@gmail.com, KCS: profchandrapal@gmail.com, VN: nkuliyadi@yahoo.com, TT: thiruclk@gmail.com, YBR: rajivinay@hotmail.com, BCU: umi_bc@rediffmail.com

Received: 29-06-2018, Accepted: 05-09-2018, Published online: 23-10-2018

doi: 10.14202/vetworld.2018.1479-1485 How to cite this article: Giridhar KS, Prabhu TM, Singh KC, Nagabhushan V, Thirumalesh T, Rajeshwari YB, Umashankar BC (2018) Nutritional potentialities of some tree leaves based on polyphenols and rumen in vitro gas production, Veterinary World, 11(10): 1479-1485.

\begin{abstract}
Aim: The study was conducted to evaluate eight tree leaves based on polyphenolic content and rumen in vitro incubation and gas production technique (RIVIGPT) for their nutritive potentiality.

Materials and Methods: Eight selected tree leaves, namely Sesbania grandiflora, Melia dubia, Dillenia spp., Artocarpus heterophyllus, Commiphora caudata, Moringa oleifera, Leucaena leucocephala, and Acacia auriculiformis, were selected for proximate composition, forage fiber fractions, total phenolics (TPs), non-tannin phenols (NTPs), total tannins (TTs), condensed tannins (CTs), and hydrolysable tannins (HTs); RIVIGP with and without polyethylene glycol (PEG); and in vitro dry matter digestibility (IVDMD) (modified in vitro two stage) analysis was conducted. On the basis of RIVIGPT, the in vitro digestible organic matter (IVDOM) and dry matter intake (DMI) was calculated.

Results: Crude protein (CP) content of tree leaves ranged from 9.59 to $25.81 \%$, neutral detergent fiber (NDF) 28.16 to $53.33 \%$, acid detergent fiber (ADF) 21.26 to $41.7 \%$, acid detergent lignin (ADL) 3.62 to $21.98 \%$, TP 1.83 to $17.35 \%$, TT 0.40 to $15.47 \%$, and CTs 0.02 to $15.26 \%$. IVDMD (\%) was ranged from 64.95 to 88.12 . The mean metabolizable energy $(\mathrm{ME})(\mathrm{MJ} / \mathrm{Kg})$ of tree leaves estimated with and without PEG was $7.75 \pm 0.56$ and $8.75 \pm 0.39$, in vitro gas production at $24 \mathrm{~h}$ (IVGP ${ }^{24}$ ) (ml) $31.06 \pm 4.14$ and $37.09 \pm 2.64$, initial gas production (a) (ml) $0.49 \pm 0.63$ and $1.33 \pm 0.72$, potential gas production (D) (ml) $38.74 \pm 4.27$ and $43.79 \pm 2.44$, rate of gas production $(k)\left(\mathrm{h}^{-1}\right) 0.11 \pm 0.02$ and $0.11 \pm 0.013, t_{1 / 2}(\mathrm{ml}) 9.81 \pm 2.41$ and $7.42 \pm 0.80$, in vitro gas production at $96 \mathrm{~h} \mathrm{IVGP}^{96}(\mathrm{ml}) 39.50 \pm 4.430$ and $45.14 \pm 2.65$, the predicted IVDOM $(\%) 55.44 \pm 4.15$ and $61.98 \pm 3.03$, and DMI $\left(\mathrm{g} / \mathrm{Kg} \mathrm{W}^{0.75}\right)$ $103.1 \pm 14.76$ and $104.3 \pm 10.16$, respectively. The addition of PEG showed an improvement in IVGP ${ }^{24}, \mathrm{IVGP}^{96}$, ME, predicted IVDOM, and predicted DMI. CP was positively correlated with ME, IVGP ${ }^{24}$, IVGP ${ }^{96}, a+b, k(\mathrm{r}=0.749, \mathrm{p}<0.05), \mathrm{IVDMD}_{\text {, }}$ IVDOM, and DMI $(\mathrm{r}=0.838, \mathrm{p}<0.05)$ and negatively correlated with $a$ and $\mathrm{t}_{12}$. NDF, ADF, and ADL contents were negatively correlated with $\mathrm{ME}(\mathrm{r}=0.899, \mathrm{p}<0.05), \operatorname{IVGP}^{24}(\mathrm{r}=-0.867, \mathrm{p}<0.05), \operatorname{IVGP}^{96}(\mathrm{r}=-0.858, \mathrm{p}<0.05), a+b(\mathrm{p}<0.05), k(\mathrm{r}=-0.828$, $\mathrm{p}<0.05)$, IVDMD, IVDOM ( $\mathrm{r}=-0.853, \mathrm{p}<0.05)$, and DMI and positively correlated with $a$ and $t_{1 / 2}$. TP, TT, and CT were negatively correlated with ME, IVGP, IVGP ${ }^{96}, a+b, k$, IVDMD, IVDOM, and DMI and positively correlated with $a(\mathrm{r}=0.808, \mathrm{p}<0.05)$ and $\mathrm{t}_{1 / 2} . \mathrm{ME}(\mathrm{MJ} / \mathrm{Kg})$ was positively correlated with $\operatorname{IVGP}^{24}(\mathrm{r}=0.938, \mathrm{p}<0.05), \operatorname{IVGP}^{96}(\mathrm{r}=0.875, \mathrm{p}<0.05), a+b(\mathrm{r}=0.813, \mathrm{p}<0.05)$, $k(\mathrm{r}=0.731, \mathrm{p}<0.05)$, IVDMD, IVDOM $(\mathrm{r}=0.985, \mathrm{p}<0.05)$, and DMI $(\mathrm{r}=0.727, \mathrm{p}<0.05)$ and negatively correlated with $a$ and $\mathrm{t}_{1 / 2}$.

Conclusion: In the present study, the potentiality of tree leaves was assessed based on CP, ADF, ADL, TP, CT, IVGP, ME, IVDMD, predicted IVDOM, and predicted DMI. Based on this, it can be concluded that S. grandiflora, M. dubia, M. Oleifera, and L. leucocephala were graded as best; A. heterophyllus and C. caudata as moderate; and Dillenia spp. and A. auriculiformis as lowest potential ruminant feed.
\end{abstract}

Keywords: chemical composition, in vitro, in vitro dry matter digestibility, in vitro digestible organic matter, metabolizable energy, polyethylene glycol, rumen in vitro incubation and gas production, ruminants, tannins, tree leaves.

\section{Introduction}

The inadequacy of nutrients is a major limitation for livestock as a deficit of $728 \mathrm{mT}(64 \%)$ of green fodder and $157 \mathrm{mT}(25 \%)$ of dry fodder with $27 \%$ of

Copyright: Giridhar, et al. Open Access. This article is distributed under the terms of the Creative Commons Attribution 4.0 International License (http://creativecommons.org/licenses/ by/4.0/), which permits unrestricted use, distribution, and reproduction in any medium, provided you give appropriate credit to the original author(s) and the source, provide a link to the Creative Commons license, and indicate if changes were made. The Creative Commons Public Domain Dedication waiver (http:// creativecommons.org/publicdomain/zero/1.0/) applies to the data made available in this article, unless otherwise stated. crude protein (CP) and $24 \%$ of total digestible nutrients in India which is expected by 2020 [1]. This can partly be overcome by feeding tree leaves, as huge quantity of biomass is available from fodder trees, which provide nitrogen, energy, minerals and vitamins and additionally have laxative effect and reduce cost of feeding [2].

Suitability of inclusion in the feeding can be assessed either by in situ or rumen in vitro incubation and gas production techniques (RIVIGPT), which would be complementary to traditional chemical measurements [3]. In comparison to in vivo feeding trial, 
the RIVIGPT is simple, less expensive, less time consuming and allow more control over experiment. As being more efficient than other in vitro techniques, it is suggested for determining the nutritive value of feeds containing anti-nutritive factors and for evaluating the microbial fermentation of ruminant feeds and its impact on fermentation products $[4,5]$.

Therefore, the present study was conducted to evaluate nutritive potentialities of eight tree leaves such as Sesbania grandiflora, Melia dubia, Dillenia spp., Artocarpus heterophyllus, Commiphora caudata, Moringa oleifera, Leucaena leucocephala, and Acacia auriculiformis of different parts of Karnataka state based on polyphenolic content and RIVIGPT. The selected tree leaves are grown in this region and used in animal feeding. Except S. grandiflora, A. heterophyllus, M. Oleifera, and L. leucocephala, other tree leaves are new to investigation and there is no literature with regard to nutritive value, and hence, this study will be useful in comparing among the tree leaves.

\section{Materials and Methods \\ Ethical approval}

The Institutional Animal Ethics Committee approved to collect rumen fluid from the cannulated cow.

\section{Collection of tree leaves and processing}

Tree leaves of $S$. grandiflora (Agase, Kan.), M. dubia (Hebbevu, Kan.), Dillenia spp. (Kaadu kanigalu, Kan.), A. heterophyllus (Halasu, Kan.), C. caudata (Konda Maavu, Kan.), M. oleifera (Nugge, Kan.), L. leucocephala (Subabul), and A. auriculiformis (Acacia) were chosen from different parts of Karnataka state. About $2-3 \mathrm{Kg}$ of tree leaves from the single source were hand plucked, oven dried at $55^{\circ} \mathrm{C}$ for $48 \mathrm{~h}$, and grounded to pass through size of $1 \mathrm{~mm}$ sieve for further analysis (Kan. regional language, Kannada).

\section{Determination of nutritive components and polyphe- nolic fractions}

These selected tree leaves were analyzed in triplicates for proximate composition, forage fiber fractions [5], total phenolics (TPs), non-tannin phenols (NTPs), total tannin phenols (TTPs), condensed tannins (CTs), and hydrolysable tannins (HTs) [4]; RIVIGP with and without polyethylene glycol (PEG) [6]; in vitro dry matter digestibility (IVDMD) (modified in vitro two stage) [7]; and prediction of in vitro digestible organic matter (IVDOM) and dry matter intake (DMI) [8].

\section{RIVIGP}

The selected tree leaves were subjected to RIVIGP (with and without PEG) for estimating metabolizable energy (ME) and rate of gas production. A lactating dairy cow producing $3 \mathrm{Kg}$ of milk per day, fitted with a flexible rumen cannula of large diameter (Bar Diamond Inc., USA), receiving a basal diet consisting of finger millet straw and CFM (maize $60 \%$, WB $35 \%$, mineral mixture $2 \%$, urea $2 \%$, and salt $1 \%$ ) was used as donor cow for rumen fluid. For
RIVIGPT, rumen fluid was collected before offering CFM.

Feed samples $(200 \pm 10 \mathrm{mg})$ were incubated with and without PEG in $100 \mathrm{ml}$ calibrated glass syringes in triplicate with $30 \mathrm{ml}$ mixed rumen suspension with three blank incubations and standards [6]. For PEG treatment, PEG is added twice the amount of feed sample, and blank samples with PEG were also incubated for estimating corrected gas production. Cumulative gas production was recorded after $2,4,6,8,12,16$, $24,36,48,60,72$, and $96 \mathrm{~h}$ of incubation.

Data on gas production were fitted to the exponential equation $Y=a+b\left(1-e^{-c t}\right)$, where $Y(\mathrm{~mL})$ was defined as gas production at time $t, a(\mathrm{~mL})$ was the initial gas production, $b(\mathrm{~mL})$ was the gas production during incubation, $a+b$ or $D(\mathrm{~mL})$ was the potential gas production, and $c(\mathrm{~mL} / \mathrm{h})$ was the fractional gas production.

The equations used to estimate the IVDOM and $\mathrm{ME}$ [5] are as follows:

$\mathrm{ME}(\mathrm{MJ} / \mathrm{Kg})=2.2+0.1357 \mathrm{GP}+0.0057 \mathrm{CP}+0.0002859$ $\mathrm{EE}^{2}$

IVDOM $(\%)=14.88+0.8893 \mathrm{GP}+0.0448 \mathrm{CP}+0.0651$ TA

Where

$\mathrm{GP}=$ Corrected net gas production, $\mathrm{ml} / 200 \mathrm{mg} \mathrm{DM}$.

$\mathrm{CP}=$ Crude protein, $\mathrm{g} / \mathrm{Kg} \mathrm{DM}$.

$\mathrm{EE}=$ Ether extract $\mathrm{g} / \mathrm{Kg} \mathrm{DM}$.

$\mathrm{TA}=$ Total ash, $\mathrm{g} / \mathrm{Kg} \mathrm{DM}$.

Predicted daily intake (DMI) $\left(\mathrm{g} \mathrm{DM}^{\mathrm{D}} \mathrm{Kg} \mathrm{W}^{0.75}\right)$ [8] was estimated using the following equation:

$D M I=18.9-0.23(a+b)+687(c)+0.11 C P(g / K g D M)$

Where $a(\mathrm{~mL})$ was the initial gas production, $b(\mathrm{~mL})$ was the gas production during incubation, and $c(\mathrm{~mL} / \mathrm{h})$ was the fractional gas production.

\section{IVDMD}

The IVDMD was carried out using Ankom ${ }^{200}$ Fiber Analyzer where F57 Ankom Filter Bag (porosity: $25 \mu$ ) was used for extraction. Bags were made up of $\mathrm{N}$-free Monofilament Polyester Screen Printing Fabrics.

About $400 \mathrm{mg}$ of dry forage samples $(2 \mathrm{~mm})$ were weighed into F57 Ankom Filter Bags and subjected for $48 \mathrm{~h}$ incubation in Mold's buffer/rumen fluid mixture in sealed Erlenmeyer flasks followed by treatment with NDS. The dry residues were weighed, and digestibility was calculated using the following equation $[7,9]$.

$\operatorname{IVDMD}(\%)=\frac{\left[\left(\begin{array}{l}\text { Initial wt. of sample }(D M)- \\ (\text { Final wt. of sample- Blank })\end{array}\right)\right]}{[\text { Initial wt. of sample }(\mathrm{DM})]} \times 100$

\section{Polyphenolic fractions}

TPs were estimated by Folin-Ciocalteu reaction [4] using gallic acid as a standard. For the CT fraction, the extract was treated with butanol- $\mathrm{HCl}$ in the presence of ferric ammonium sulfate, and CT expressed as leukocyanidin equivalent as $A 550 \mathrm{~nm} \times 782.6$ weight 
of sample DM, where $A 550 \mathrm{~nm}$ is absorbance at $550 \mathrm{~nm}$ assuming that the effective $E 1 \%, 1 \mathrm{~cm}, 550 \mathrm{~nm}$ of leukocyanidin is 460 . The phenolic content of the supernatant after precipitating with polyvinylpolypyrrolidone (100 mg) was measured by the Folin-Ciocalteu reaction and this was regarded as the NTP. TTPs were calculated as the difference between TP and NTP. HTs were calculated as the difference between TTP and CT.

\section{Statistical analysis}

The data on RIVIGP were subjected to nonlinear regression using GraphPad Prism software to assess gas kinetics (exponential decay equation model). Pearson correlation analysis was used to assess the relationship between chemical composition and ME, IVGP ${ }^{24}$ (in vitro gas production at $24 \mathrm{~h}$ ), $\mathrm{IVGP}^{96}$ (in vitro gas production at $96 \mathrm{~h}$ ), IVDMD, IVDOM, and DMI of the tree leaves.

\section{Results}

\section{Chemical composition}

The nutrient composition of the tree leaf samples is presented in Table-1. The DM content of fresh tree leaves was low in S. grandiflora (20.31\%) and high in A. heterophyllus (37.45\%). The OM content was low in C. caudata (87.97\%) and high in A. auriculiformis (93.95\%). The CP content ranged from $9.59 \%$ (Dillenia spp.) to $25.81 \%$ (L. leucocephala). The level of NDF ranged from $28.16 \%$ (L. leucocephala) to $53.33 \%$ (Dillenia spp.). The ADF ranged from $21.26 \%$ (S. grandiflora) to $41.7 \%$ (Dillenia spp.). The level of ADL ranged from $3.62 \%$ (S. grandiflora) to $21.98 \%$ (A. auriculiformis).

\section{Polyphenolic fractions}

Polyphenolic fractions (on DM basis) of the eight tree leaves are presented in Table-2 [4]. The TP content of tree leaves was high in A. heterophyllus $(17.35 \%)$ and low in S. grandiflora $(1.77 \%)$. The NTP was rich in Dillenia spp. (5.7\%) and low in S. grandiflora $(1.00 \%)$. TTP content was more in A. heterophyllus $(15.47 \%)$ and low in M. oleifera $(0.40 \%)$. The potent source of CT and HT was A. heterophyllus (15.26\%) and Dillenia spp. (4.72\%), respectively.

\section{Gas production kinetics}

RIVIGP values of tree leaves with or without PEG are shown in Table-3. The IVGP ${ }^{24}(\mathrm{ml})$ was more in M. oleifera (42.63) and less in A. auriculiformis (8.68). The IVGP ${ }^{96}(\mathrm{ml})$ was higher for $S$. grandiflora $(50.54)$ and less for A. auriculiformis (10.27). The $D(\mathrm{ml})$ value was more in S. grandiflora (47.48) and lower for A. auriculiformis (9.64). $k$ was higher for M. dubia and lower for Dillenia spp., and $\mathrm{t}_{1 / 2}(\mathrm{~h})$ was highest for Dillenia spp. and least for M. dubia. Among the evaluated tree leaves, energy content (ME, $\mathrm{MJ} / \mathrm{Kg}$ ) was higher in $S$. grandiflora (9.87) and lower in A. auriculiformis (5.03).

\section{IVDMD}

IVDMD of tree leaves was analyzed using Ankom ${ }^{200}$ Fiber analyzer based on modified in vitro two-stage method which is shown in Table-4. IVDMD of tree leaves ranged from $64.95 \%$ (A. auriculiformis) to $88.12 \%$ (M. dubia) and an average of $76.02 \%$.
ต $\mid$ กุ

I

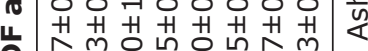

ডิ

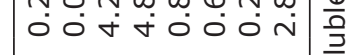

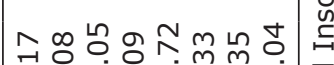

a

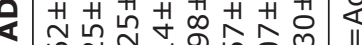
mं

ڤิ용

L

ब

त्र

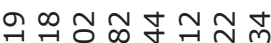

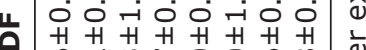

$\mathbf{2}$

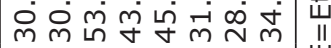

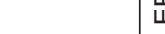

ㄲํำ 8 ํํำ

$\varangle$ o 0 i o o o o o o

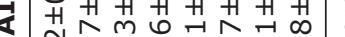

$00-4 m 0 \infty \infty$

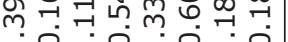

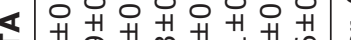

мо의의

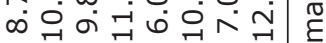

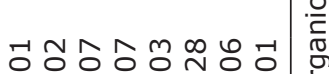

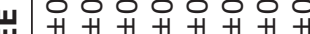
N

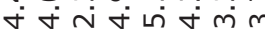

m우 0 ㄴ $m$ m $m$ N.

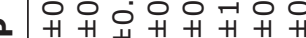

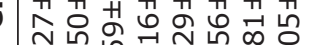

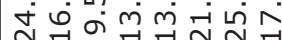
政

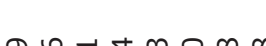

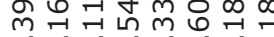

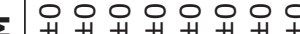

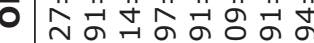
त. कू का नी

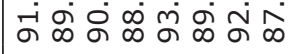

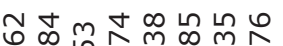
o r o o no

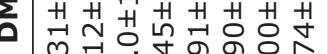
ஸें

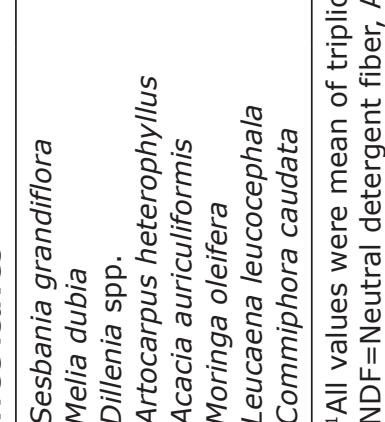


Table-2: Polyphenolic fractions (\%) of tree leaves on DMB.

\begin{tabular}{lcccrr}
\hline Tree leaves & TP & NTP & TTP $^{\mathbf{1}}$ & CT $^{\mathbf{4}}$ & HT $^{\mathbf{5}}$ \\
\hline Sesbania grandiflora & $1.77 \pm 0.06$ & $1.00 \pm 0.03$ & $0.77 \pm 0.02$ & $0.02 \pm 0.01$ & $0.75 \pm 0.05$ \\
Melia dubia & $1.89 \pm 0.11$ & $1.11 \pm 0.02$ & $0.77 \pm 0.06$ & $0.19 \pm 0.02$ & $0.58 \pm 0.03$ \\
Dillenia spp. & $11.67 \pm 0.56$ & $5.70 \pm 0.40$ & $5.97 \pm 0.43$ & $1.25 \pm 0.01$ & $4.72 \pm 0.35$ \\
Artocarpus heterophyllus & $17.35 \pm 0.14$ & $1.88 \pm 0.01$ & $15.47 \pm 0.19$ & $15.26 \pm 0.01$ & $0.21 \pm 0.03$ \\
Acacia auriculiformis & $9.04 \pm 0.66$ & $4.95 \pm 0.14$ & $4.09 \pm 0.08$ & $2.37 \pm 0.05$ & $1.72 \pm 0.01$ \\
Moringa oleifera & $1.83 \pm 0.19$ & $1.44 \pm 0.03$ & $0.40 \pm 0.08$ & $0.19 \pm 0.01$ & $0.20 \pm 0.07$ \\
Leucaena leucocephala & $4.76 \pm 0.12$ & $2.68 \pm 0.15$ & $2.07 \pm 0.20$ & $1.99 \pm 0.01$ & $0.09 \pm 0.08$ \\
Commiphora caudata & $4.98 \pm 0.22$ & $3.35 \pm 0.32$ & $1.63 \pm 0.26$ & $1.25 \pm 0.01$ & $0.38 \pm 0.11$ \\
\hline
\end{tabular}

All values were mean of triplicates. ${ }^{1}$ TP by Folin-Ciocalteu reaction [4]. ${ }^{2}$ NTP by Folin-Ciocalteu reaction using PVPP [4]. ${ }^{3}$ TTP by difference between TP and NTP. ${ }^{4} \mathrm{CT}$ expressed as leukocyanidin equivalent. ${ }^{5} \mathrm{HT}$ calculated by difference between TTP and CT. TP=Total phenol, NTP=Non-tannin phenol, TTP=Total tannin phenol, $C T=C o n d e n s e d$ tannin, $\mathrm{HT}=$ Hydrolysable tannin, DMB=Dry matter basis

\section{Prediction of IVDOM and DMI}

The IVDOM and DMI were predicted based on gas production and chemical composition of tree leaves which are presented in Table-4. IVDOM was ranged from 32.52 (A. auriculiformis) to 69.05 ( $S$. grandiflora) and the predicted DMI $\left(\mathrm{g} / \mathrm{Kg} \mathrm{W}^{0.75}\right)$ was ranged from $41.9 \mathrm{~g}$ Dillenia spp. to $136.8 \mathrm{~g}$ (M. dubia).

\section{Effect of PEG on gas production kinetics, IVDOM, and DMI}

The PEG inclusion during incubation resulted in increased ME, $a, D$, IVGP ${ }^{24}$, $\mathrm{k}$, IVGP ${ }^{96}$, IVDOM, and DMI of tree leaves and decreasedt ${ }_{1 / 2}$. In Dillenia spp., A. heterophyllus, and A. auriculiformis tree leaves, it was more pronounced.

\section{Correlation analysis $(r)$}

Pearson correlation analysis was made to test the relationship between chemical composition and ME, IVGP ${ }^{24}$, IVGP ${ }^{96}$, IVDMD, IVDOM, and DMI values and is presented in Table-5. CP was positively correlated with $\mathrm{ME}$, IVGP ${ }^{24}$, IVGP ${ }^{96}, a+b$, $k(\mathrm{r}=0.749, \mathrm{p}<0.05)$, IVDMD, IVDOM, and DMI $(\mathrm{r}=0.838, \mathrm{p}<0.05)$ and negatively correlated with $a(\mathrm{r}=-0.451)$ and $\mathrm{t}_{1 / 2}(\mathrm{r}=-0.575)$. NDF, ADF, and ADL contents are negatively correlated with $\mathrm{ME}$ $(\mathrm{r}=-0.899, \quad \mathrm{p}<0.05), \quad \operatorname{IVGP}^{24}(\mathrm{r}=-0.867, \mathrm{p}<0.05)$, $\operatorname{IVGP}^{96}(\mathrm{r}=-0.858, \mathrm{p}<0.05), a+b(\mathrm{r}=-0.828, \mathrm{p}<0.05)$, $k(\mathrm{r}=-0.877, \mathrm{p}<0.05)$, IVDMD $(\mathrm{r}=-0.674)$, IVDOM $(\mathrm{r}=-0.853, \mathrm{p}<0.05)$, and DMI $(\mathrm{r}=-0.538)$ and positively correlated with $a(\mathrm{r}=0.424)$ and $t_{1 / 2}(\mathrm{r}=0.683)$. TP, TTP, and CT are negative correlation of non-significant difference with ME, IVGP ${ }^{24}$, IVGP ${ }^{96}, a+b, k$, IVDMD, IVDOM, and DMI and positively correlated with $a(\mathrm{r}=0.808, \mathrm{p}<0.05)$ and $\mathrm{t}_{1 / 2}$. The initial gas production was more in tannin-containing feeds which may due to easily degradable OM. At $96 \mathrm{~h}$ incubation, tannins inhibited the gas production (negative correlation) which may be due to fiber bound tannins in tree leaves. The negative relationship between chemical composition and phenolic compounds, with in vitro degradability of legumes at $24 \mathrm{~h}$ of in vitro incubation may be due to presence of ADF and CT in them, but on addition of PEG reversed that situation $[3,10,11]$. $\mathrm{ME}(\mathrm{MJ} / \mathrm{Kg})$ was positively correlated with $\mathrm{IVG}^{\mathrm{P} 24}$ $(\mathrm{r}=0.938, \mathrm{p}<0.05), \mathrm{IVG}^{\mathrm{P} 96}(\mathrm{r}=0.875, \mathrm{P}<0.05),(a+b)$ $(\mathrm{r}=0.813, \mathrm{p}<0.05), \mathrm{k} \quad(\mathrm{r}=0.731, \mathrm{p}<0.05)$, IVDMD, IVDOM $(\mathrm{r}=0.985, \mathrm{p}<0.05)$, and DMI $(\mathrm{r}=0.727$, $\mathrm{p}<0.05)$ and negatively correlated with a and $t_{1 / 2}$.

\section{Discussion}

\section{Chemical composition}

In the present study, $\mathrm{CP}$ varied from 9.59 to $25.81 \%$, and it was in similar range for tree leaves as in published reports [12-17]. Similarly, the NDF, $\mathrm{ADF}$, and ADL contents of analyzed tree leaves were in a instead of the similar range $[13,18,19]$.

In the present study, there were considerable variations in chemical compositions between the tree leaves. This was due to differences in genotype, environment, stage of maturity, and harvesting [20-22]. The multipurpose tree leaves contained moderate levels of CP, minerals, and vitamins that are deficient in many low-quality roughages and it was found that $\mathrm{CP}$ level above the threshold level (11-12\%) is required for the moderate level of ruminant production [23].

\section{Polyphenolic fractions}

The literature on the polyphenolic content of tree leaves depicts that the concentration remarkably varies from source to source. The polyphenolic content estimated was lower $[17,24,25]$ than the present values, whereas a similar range of values was also observed in the past [15,16,26-28].

Tannin composition in plants depends on type of plant, photosynthetic capacity, soil fertility, environmental conditions, maturity of the leaves, and processing and analytical method employed in analysis [4]. In general, the intake of CT below 5\% improves the utilization of feed by ruminants, mainly because of a reduction in ruminal protein degradation and, as a consequence, greater availability of mainly essential amino acids for absorption in the small intestine. Values of CTs exceeding 5\% on dry matter basis could inhibit microbial activity, depress dry matter digestibility, and reduce voluntary intake [29].

\section{Gas production kinetics}

In the present study, the lower level of $\mathrm{ME}$ and RIVIGP parameters is closely related to its CP, fiber fractions, and tannins as reported by previous studies $[24,30,31,32,33]$. 


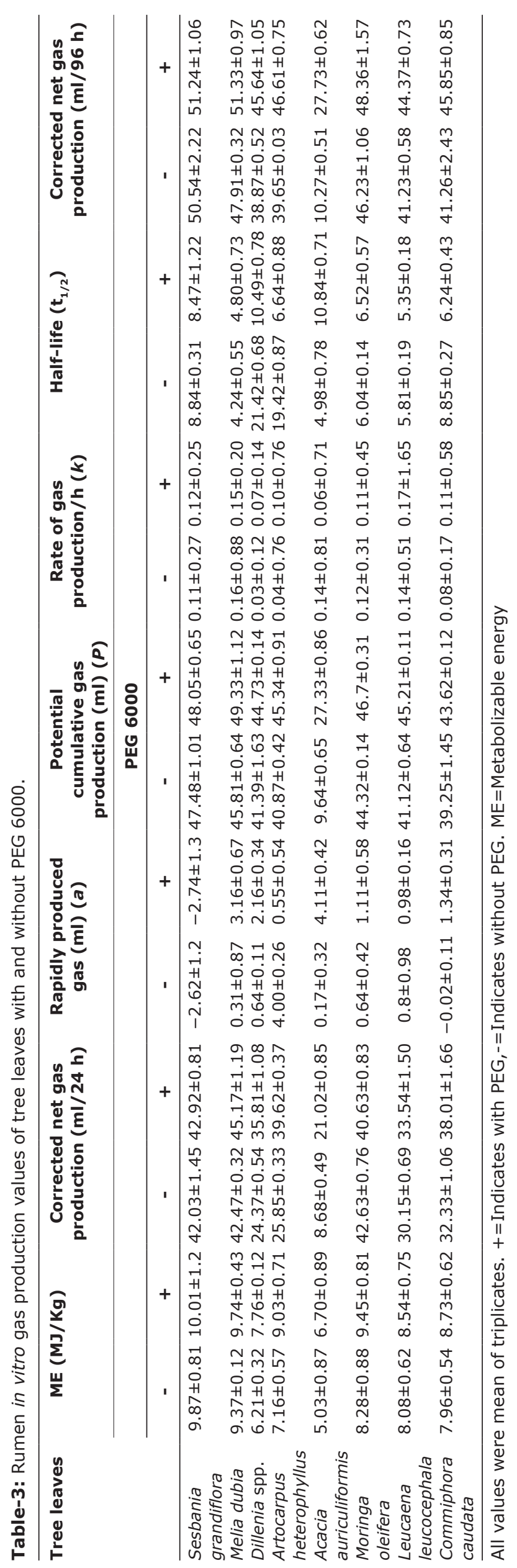

\section{IVDMD and prediction of IVDOM and DMI}

IVDMD of tree leaves ranged from $64.95 \%$ (A. auriculiformis) to $88.12 \%$ (M. dubia) and an average value of $76.02 \%$, whereas in previous study, it was found the range of IVDMD in tree leaves between 22.70 and $58.72 \%$ that was lower than the present study which may arise due to lower quality of tree leaves [19]. The predicted IVDOM ranged from 32.52 (A. auriculiformis) to 69.05 (S. grandiflora) with an average value of $55.43 \%$, and the predicted DMI ( $\mathrm{g} / \mathrm{Kg} \mathrm{W}^{0.75}$ ) was lowest in Dillenia spp. (42.2 g) with an average value of $103.13 \mathrm{~g}$.

\section{Effect of PEG on kinetics of gas production}

The improvement in gas production in Dillenia spp., A. heterophyllus, and A. auriculiformis tree leaves was due to affinity of PEG to tannins[32-35]. It was also found that there was only minor improvement in IVGP $^{24}$ and IVGP ${ }^{96}$ in L. leucocephala and C. caudata due to the low level of CT in them. Addition of PEG also increased the ME, IVDOM \% content, and DMI $\left(\mathrm{g} / \mathrm{KgW}^{0.75}\right)$ in these tree leaves.

In general, the improvement in fermentation in each species by adding PEG almost certainly reflects its deactivation of secondary compounds $[11,35,36]$. High CT (proanthocyanidins) and fiber (NDF and ADF) contents reduce digestibility $[31,32]$ while low $\mathrm{CP}$ affects the acceptability of browse [25]. Similarly, in the present study, lower level of IVGP was observed in those tree leaves which are containing more CT, NDF, ADF, and ADL.

Based on ME, ADL, and predicted DMI of tree leaves, it can be categorized as best, moderate and poor potential source of fodders for ruminants [26]. S. grandiflora, M. dubia, M. oleifera, and L. leucocephala were best potential fodders due to higher $\mathrm{ME}$ $(>8.08 \mathrm{MJ})$ and predicted DMI ( $>111 \mathrm{~g})$ and lower $\operatorname{ADL}(<8.62 \%) ;$ A. heterophyllus and $C$. caudata were moderate potential due to moderate in $\mathrm{ME}(7-7.96 \mathrm{MJ})$ and predicted DMI (48.7-82.4 g) and slightly higher ADL (9-15.3\%), whereas, Dillenia spp. and A. auriculiformis were lowest potentiality due to lower $\mathrm{ME}$ (5-6.2 MJ) and predicted DMI (41-48.1 g) and very higher ADL (15.25-21.98\%) in them.

\section{Conclusion}

In the present study, the nutritive potentiality of tree leaves was assessed based on CP, ADF, ADL, TP, CT, IVGP, ME, IVDMD, IVDOM, and DMI. It can be concluded that $S$. grandiflora, $M$. dubia, M. oleifera, and L. leucocephala were graded as the best due to higher CP, ME, IVGP, IVDMD, IVDOM and DMI and lower polyphenols and fiber fractions; $A$. heterophyllus and $C$. caudata were graded as the moderate potential and Dillenia sp. and A. auriculiformis were graded as the lowest potential as a ruminant feed. While the addition of PEGin Dillenia spp. and A. auriculiformis improved the RIVIGP but it did not impact their overall nutritive ranking. However, more studies are required to characterize these feeds better 
Table 4: IVDMD and predicted IVDOM and DMI $\left(\mathrm{g} / \mathrm{Kg} \mathrm{W}^{0.75}\right)$ of tree leaves.

\begin{tabular}{|c|c|c|c|c|c|}
\hline \multirow[t]{3}{*}{ Tree leaves } & \multirow[t]{3}{*}{ IVDMD $^{1}$} & \multicolumn{2}{|c|}{ IVDOM $^{2}(\%)$} & \multicolumn{2}{|c|}{$\mathrm{DMI}^{3}\left(\mathrm{~g} / \mathrm{Kg} \mathrm{W}^{0.75}\right)$} \\
\hline & & \multicolumn{4}{|c|}{ PEG 6000} \\
\hline & & - & + & - & + \\
\hline Sesbania grandiflora & $78.93 \pm 1.11$ & $69.05 \pm 0.41$ & $69.84 \pm 0.42$ & $110.2 \pm 0.21$ & $116.3 \pm 0.39$ \\
\hline Melia dubia & $88.12 \pm 2.43$ & $66.61 \pm 0.17$ & $69.01 \pm 0.31$ & $136.8 \pm 0.42$ & $125.0 \pm 0.51$ \\
\hline Dillenia spp. & $75.92 \pm 1.43$ & $47.27 \pm 0.42$ & $57.44 \pm 0.18$ & $41.9 \pm 0.17$ & $64.6 \pm 0.28$ \\
\hline Artocarpus heterophyllus & $71.43 \pm 1.78$ & $50.94 \pm 0.32$ & $63.19 \pm 0.42$ & $48.7 \pm 0.53$ & $94.7 \pm 0.61$ \\
\hline Acacia auriculiformis & $64.95 \pm 1.86$ & $32.52 \pm 0.19$ & $43.50 \pm 0.38$ & $48.1 \pm 0.42$ & $71.2 \pm 0.51$ \\
\hline Moringa oleifera & $86.26 \pm 1.32$ & $60.10 \pm 0.22$ & $67.77 \pm 0.32$ & $111.4 \pm 0.38$ & $104.9 \pm 0.43$ \\
\hline Leucaena leucocephala & $70.62 \pm 0.64$ & $57.87 \pm 1.21$ & $60.88 \pm 0.19$ & $134.0 \pm 0.52$ & $153.7 \pm 0.58$ \\
\hline Commiphora caudata & $71.96 \pm 0.71$ & $59.12 \pm 0.82$ & $64.17 \pm 0.91$ & $82.4 \pm 0.72$ & $103.9 \pm 0.75$ \\
\hline
\end{tabular}

All values were mean of triplicates. ${ }^{+}$Indicates with PEG and -indicates without PEG. ${ }^{1}$ IVDMD (\%) - As per modified two-stage fermentation using Ankom ${ }^{200}$ Fiber Bag Analyzer. ${ }^{2}$ IVDOM (\%) $=14.88+0.8893 \mathrm{GP}+0.0448 \mathrm{CP}+0.0651$

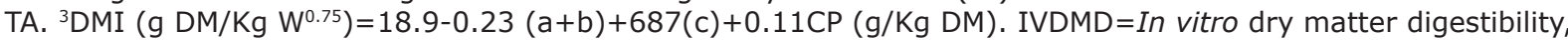
IVDOM=In vitro digestible organic matter, $\mathrm{PEG}=$ Polyethylene glycol, DMI=Dry matter intake

Table-5: Correlation coefficients $(r)$ between in vitro fermentation parameters, IVDMD, IVDOM, and DMI with chemical composition and total phenolics and tannins.

\begin{tabular}{|c|c|c|c|c|c|c|c|c|c|}
\hline Parameter & PEG & $\mathbf{C P}$ & NDF & ADF & ADL & TP & TTP & CT & ME (MJ/Kg) \\
\hline \multirow[t]{2}{*}{$\mathrm{ME}(\mathrm{MJ} / \mathrm{Kg})$} & - & 0.684 & $-0.822 *$ & $-0.899 *$ & $-0.849 *$ & -0.673 & -0.448 & -0.280 & - \\
\hline & + & 0.543 & -0.700 & $-0.774^{*}$ & $-0.906 *$ & -0.480 & -0.214 & -0.046 & - \\
\hline \multirow[t]{2}{*}{ IVGP24 } & - & 0.576 & $-0.722 *$ & $-0.800 *$ & $-0.867 *$ & -0.666 & -0.459 & -0.327 & $0.938^{*}$ \\
\hline & + & 0.275 & -0.472 & -0.581 & $-0.797^{*}$ & -0.328 & -0.106 & -0.017 & $0.848^{*}$ \\
\hline \multirow[t]{2}{*}{ IVGP96 } & - & 0.465 & -0.560 & -0.678 & $-0.858 *$ & -0.413 & -0.218 & -0.132 & $0.875^{*}$ \\
\hline & + & 0.346 & -0.474 & -0.604 & $-0.824 *$ & -0.332 & -0.133 & -0.063 & $0.844^{*}$ \\
\hline \multirow[t]{2}{*}{ a } & - & -0.451 & 0.362 & 0.424 & 0.128 & $0.752 *$ & $0.808 *$ & $0.826 *$ & -0.413 \\
\hline & + & -0.586 & 0.411 & 0.489 & $0.708^{*}$ & 0.191 & 0.022 & -0.066 & -0.629 \\
\hline \multirow[t]{2}{*}{$a+b$} & - & 0.384 & -0.457 & -0.593 & $-0.828 *$ & -0.299 & -0.117 & -0.058 & $0.801 *$ \\
\hline & + & 0.368 & -0.476 & -0.613 & $-0.830 *$ & -0.300 & -0.108 & -0.040 & $0.813^{*}$ \\
\hline \multirow[t]{2}{*}{$\mathrm{k}$} & - & 0.402 & -0.470 & -0.418 & 0.073 & -0.597 & -0.602 & -0.487 & 0.099 \\
\hline & + & $0.749 *$ & $-0.854 *$ & $-0.877^{*}$ & -0.638 & -0.498 & -0.320 & -0.112 & $0.731^{*}$ \\
\hline \multirow[t]{2}{*}{$t_{1 / 2}$} & - & -0.575 & 0.683 & 0.570 & 0.069 & $0.766 *$ & $0.735^{*}$ & 0.559 & -0.290 \\
\hline & + & -0.501 & $0.764 *$ & 0.705 & 0.587 & 0.366 & 0.156 & -0.076 & -0.672 \\
\hline IVDMD & - & 0.228 & -0.425 & -0.548 & -0.674 & -0.572 & -0.421 & -0.378 & 0.691 \\
\hline \multirow[t]{2}{*}{$\operatorname{IVDOM}^{2}(\%)$} & - & 0.633 & $-0.774 *$ & $-0.853^{*}$ & $-0.841^{*}$ & -0.642 & -0.434 & -0.287 & $0.985^{*}$ \\
\hline & + & 0.487 & -0.644 & $-0.718^{*}$ & $-0.872 *$ & -0.460 & -0.227 & -0.091 & $0.921 *$ \\
\hline \multirow[t]{2}{*}{$\operatorname{DMI}^{4}\left(\mathrm{~g} / \mathrm{Kg} \mathrm{W} \mathrm{W}^{0.75}\right)$} & - & 0.494 & -0.538 & -0.485 & 0.005 & -0.637 & -0.629 & -0.498 & 0.159 \\
\hline & + & $0.838 *$ & $-0.900 *$ & $-0.906^{*}$ & -0.646 & -0.560 & -0.387 & -0.168 & $0.727 *$ \\
\hline
\end{tabular}

$* \mathrm{p}<0.05$; +indicates with PEG and -indicates without PEG. CP=Crude protein, NDF=Neutral detergent fiber, $A D F=A c i d$ detergent fiber, $A D L=A c i d$ detergent lignin, $T P=$ Total phenolic, TTPs=Total tannin phenols, $C T s=$ Condensed tannins, $\mathrm{ME}=$ Metabolizable energy $(\mathrm{MJ} / \mathrm{Kg} \mathrm{DM}), \mathrm{IVGP}^{24}=$ Gas production volume $(\mathrm{ml} / 0.2 \mathrm{~g} \mathrm{DM})$ after $24 \mathrm{~h}$ of incubation, IVGP $^{96}=$ Gas production volume $(\mathrm{ml} / 0.2 \mathrm{~g} \mathrm{DM})$ after $96 \mathrm{~h}$ of incubation, a=Rapidly produced gas $(\mathrm{ml}), a+b=$ Potential cumulative gas production $(\mathrm{ml}), \mathrm{k}=$ Rate of gas production/ $\mathrm{h}, \mathrm{t} 1 / 2=$ Half-life, IVDMD=In vitro DM digestibility $(\mathrm{g} / \mathrm{Kg} \mathrm{DM})$, IVDOM = In vitro digestibility of organic matter $(\%)$, DMI=Dry matter intake $\left(\mathrm{g} / \mathrm{Kg} \mathrm{W} \mathrm{W}^{0.75}\right), P E G=$ Polyethylene glycol

through in vivo feeding trials with respect to palatability and intake.

\section{Authors' Contributions}

TMP and KCS planned and supervised the entire research work. KSG carried out the experimental work and laboratory analysis. VN, TT, YBR, and BCU prepared the manuscript along with data analysis. All authors read and approved the final manuscript.

\section{Acknowledgments}

The authors are thankful to Veterinary College, Bengaluru, KVAFSU, Bidar, for providing necessary facilities for carrying out the doctoral research work of the first author. No fund was received for the present study.

\section{Competing Interests} interests.

The authors declare that they have no competing

\section{References}

1. GOI. (2012) Report of the Working Group on Animal Husbandry and Dairying. 12 $2^{\text {th }}$ Five Year Plan, 2012-2017. Planning Commission, New Delhi.

2. Devendra, C. (1992) Nutritional potential of fodder trees and shrubs as protein sources in ruminant nutrition. Legume trees and other fodder trees as protein sources for livestock. FAO Anim. Prod. Health Pap, 102: 50-62.

3. Carlos, A.S.C., Henry, L.L.S. and Francisco, J.S.S. (2005) Chemical composition, in vitro gas production and in situ degradability. Anim. Feed Sci. Technol., 123-124(12): 277-289.

4. Makkar, H.P.S. (2003) Effects and fate of tannins in ruminant animals, adaptation to tannins, and strategies to 
overcome detrimental effects of feeding tannin-rich feeds. Small Rumin. Res., 49(3): 241-256.

5. Van Soest, P.J., Robertson, J.B. and Lewis, B.A. (1991) Methods for dietary, neutral detergent fiber, and non-starch polysaccharides in relation to animal nutrition. J. Dairy Sci., 74(10): 3583-3589.

6. Menke, K.H. and Steingass, H. (1988) Estimation of the energetic feed value from chemical analysis and in vitro gas production using rumen fluid. Anim. Res. Dev., 28: 47-55.

7. Goering, H.K. and Van Soest, P.J. (1970) Forage Fibre Analysis. Agricultural Handbook. Agricultural Research Services, US. Department of Agriculture, Washington, D.C.

8. Khazaal, K., Dentinho, J.M., Ribeiro, J.M. and Ørskov, E.R. (1995) Prediction of apparent digestibility and voluntary intake of hays fed to sheep: Comparison between using fibre components, in vitro digestibility or characteristics of gas production or nylon bag degradation. Anim. Sci., 61(3): 527-538.

9. Mould, F.L., Morgan, R., Morgan, R.E., Kliem, K.E. and Krystallidou, E. (2005) A review and simplification of the in vitro incubation medium. Anim. Feed Sci. Technol., 123: 155-172.

10. Yisehak, K. and Janssens, G.P.J. (2013) Evaluation of nutritive value of leaves of tropical tanniferous trees and shrubs. Livest. Res. Rural Dev., 25(2): 14-21.

11. Salem, A.Z.M., Salem, M.Z.M., El-Adawy, M.M. and Robinson, P.H. (2006) Nutritive evaluations of some browse tree foliages during the dry season: Secondary compounds, feed intake and in vivo digestibility in sheep and goats. Anim. Feed Sci. Technol., 127(3-4): 251-267.

12. Patel, V.R., Choubey, M., Raval, A.P. and Desai, M.C. (2018) Influence of feeding Albizia lebbeck and Terminalia arjuna leaves on growth performance and nutrient utilization in Surti kids. Indian J. Anim. Nutr., 35(1): 76-81.

13. Raja, K.K. and Parthasarathy, M. (2009) In vitro nitrogen degradability of some forages, top feeds and fibrous crop residues. Anim. Feed Sci. Technol., 9: 97-101.

14. Sultana, N., Alimon, A.R., Huque, K.S., Sazili, A.Q., Yaakub, H., Hossain, J. and Baba, M. (2015) The feeding value of Moringa (Moringa oleifera) foliage as replacement to conventional concentrate diet in Bengal goats. Adv. Anim. Vet. Sci., 3(3): 164-173

15. Jayanegara, A., Wina, E., Soliva, C.R., Marquardt, S., Kreuzer, M. and Leiber, F. (2011) Dependence of forage quality and methanogenic potential of tropical plants on their phenolic fractions as determined by principal component analysis. Anim. Feed Sci. Technol., 163(2-4): 231-243.

16. Reddy, D.V. and Elanchezhian, N. (2008) Evaluation of tropical tree leaves as ruminant feedstuff based on cell contents, cell wall fractions and polyphenolic compounds. Livest. Res. Rural Dev., 20(5): 50-55.

17. Pal, L., Patra, A.K., Sahoo, A. and Kumawat, P.K. (2015) Evaluation of several tropical tree leaves for methane production potential, degradability and rumen fermentation in vitro. Livest. Sci., 180: 98-105.

18. Mishra, A.S., Tripathi, M.K., Vaithiyanathan, S. and Jakhmola, R.C. (2013) Nutritional evaluation of fallen tree leaves as source of roughage in complete feed blocks for sheep. Anim. Nutr. Feed Technol., 13(2): 223-234.

19. Girma, M., Getachew, A. and Getinet, A. (2015) Chemical composition and in vitro organic matter digestibility of major indigenous fodder trees and shrubs in Northeastern Drylands of Ethiopia. Livest. Res. Rural Dev., 27(2): 26.

20. Arhab, R., Macheboeuf, D., Aggoun, M., Bousseboua, H., Viala, D. and Besle, J.M. (2009) Effect of polyethylene glycol on in vitro gas production and digestibility of tannin-containing feedstuffs from North African arid zone Trop. Subtrop. Agroecosyst., 10(3): 475-486.

21. Elghandour, M.M.Y., Va'zquez-Chagoya'n, J.C., Salem, A.Z.M., Kholif, A.E., Martı'nez Castañeda, J.S.,
Camacho, L.M. and Cerrillo-Soto, M.A. (2014) Effects of Saccharomyces cerevisiae at direct addition or pre-incubation on in vitro gas production kinetics and degradability of four fibrous feeds. Ital. J. Anim. Sci., 13(2): 295-301.

22. Ramachandran, M., Bharathidhasan, A. and Balakrishnan, V. (2015) Nutrient composition, in vitro true digestibility (IVTD) and methane production potential of fodder tree leaves. Ind. J. Anim. Sci., 85(5): 494-497.

23. ARC. (1984) The Nutritive Requirements of Ruminant Livestock. Agricultural Research Council. Commonwealth Agricultural Bureau, Farnham, Royal, UK.

24. Singh, S., Pathak, A.K., Sharma, R.K. and Khan, M. (2015) Effect of tanniferous leaf meal based multi-nutrient blocks on feed intake, haematological profile, immune response and body weight changes in Haemonchus contortus infected goats. Vet. World, 8(5): 572-579.

25. Dey, A., Dutta, N., Sharma, K. and Pattanaik, A.K. (2008) Effect of dietary inclusion of Ficus infectoria leaves as a protectant of proteins on the performance of lambs. Small Rum. Res., 75(2-3): 105-114.

26. Chander, D., Datta, M. and Singh, N.P. (2008) Assessment of fodder quality of leaves of multipurpose trees in subtropical humid climate of India. J. For. Res., 19(3): 209-214.

27. Baruah, L., Malik, P.K., Kolte, A.P., Dhali, A. and Bhatta, R. (2018) Methane mitigation potential of phyto-sources from Northeast India and their effect on rumen fermentation characteristics and protozoa in vitro. Vet. World, 11(6): 809-818.

28. Khan, N., Ankur, R., Keshab, B., Sharma, R.K. and Yasir, B. (2014) Effect of feeding mixed silage of oat fodder and jamun leaves on nutrient utilization in goats. Indian J. Anim. Sci., 84(1): 85-87.

29. Min, B.R., Barry, T.N., Attwood, G.T. and Mcnabb, W.C. (2003) The effect of condensed tannins on the nutrition and health of ruminants fed fresh temperate forages: A review. Anim. Feed Sci. Technol., 106(1-4): 3-19.

30. Kamalak, A., Canbolat, O., Gurbuz, Y., Ozay, O. and Ozkose, E. (2005) Chemical composition and its relationship to in vitro gas production of several tannin containing tree and shrubs leaves. Asian Aust. J. Anim. Sci., 18(2): 203-208.

31. Gemeda, B.S. and Hassen, A. (2015) Effect of tannin and species variation on in vitro digestibility, gas, and methane production of tropical browse plants. Asian Australas. $J$. Anim. Sci., 28(2): 188-199.

32. Huyen, N.T., Fryganas, C., Uittenbogaard, G., MuellerHarvey, I., Verstegen, M.W.A., Hendriks, W.H. and Pellikaan, W.F. (2016) Structural features of condensed tannins affect in vitro ruminal methane production and fermentation characteristics. J. Agric. Sci., 154(8): 1474-1487.

33. Hatew, B., Stringano, E., Mueller-Harvey, I., Hendriks, W.H., Carbonero, C.H., Smith, L.M.J. and Pellikaan, W.F. (2016) Impact of variation in structure of condensed tannins from sainfoin (Onobrychis viciifolia) on in vitro ruminal methane production and fermentation characteristics. J. Anim. Physiol. Anim. Nutr., 100(2): 348-360.

34. Makkar, H.P.S., Blummel, M. and Becker, K. (1995) Formation of complexes between polyvinyl-polypyrrolidone or polyethylene glycol and tannins and their implications in gas production and true digestibility in in vitro techniques. Br. J. Nutr., 73(6): 897.

35. Salem, A.Z.M., Robinson, P.H., El-Adawy, M.M. and Hassan, A.A. (2007) In vitro fermentation and microbial protein synthesis of some browse tree leaves with or without addition of polyethylene glycol. Anim. Feed Sci. Tech., 138(3): 318-330.

36. Rajkumar, K., Bhar, R., Kannan, A., Jadhav, R.V., Singh, B. and Mal, G. (2015) Effect of replacing oat fodder with fresh and chopped oak leaves on in vitro rumen fermentation, digestibility and metabolizable energy. Vet. World., 8(8): 1021-1026. 